\title{
Population constraints on the Grenada Dove Leptotila wellsi: preliminary findings and proposals from south-west Grenada
}

\author{
N. M. BOLTON, C. van OOSTERHOUT, N. J. COLLAR and D. J. BELL
}

\begin{abstract}
Summary
The Critically Endangered Grenada Dove Leptotila wellsi has a very small total population size (<190 individuals) and faces multiple threats. Over eight weeks in 2012 at the Mount Hartman Estate, we investigated the dove's habitat selection, established a mongoose index of occupancy and recorded dove use of water sources to help determine key research and conservation needs. Of 12 habitat variables measured, greater levels of canopy cover were the best predictor of dove presence. Tracking tunnels indicated that introduced small Indian mongooses Herpestes auropunctatus, widely known for negatively impacting Caribbean bird populations, have a high level of occupancy in dove habitat, providing baseline mongoose data. Trail cameras revealed that Grenada Doves make good use of water from man-made wells and mongooses scent-mark tunnels. We urge fuller habitat selection studies and water-provision experiments to validate this evidence; strong and immediate control of mongooses and other potential predators, particularly at the nest; and a census backed by a banding programme to establish a monitoring baseline to guide conservation actions.
\end{abstract}

\section{Introduction}

The Grenada Dove Leptotila wellsi, endemic to the island of Grenada in the Caribbean, was a rare species for most of the 2oth century following the clearance of much of its forest habitat for sugarcane production (Devas 1943). It has been classified as 'Critically Endangered' since the first introduction of this highest level of IUCN threat category (BirdLife International 2014). It is restricted to $<10 \mathrm{~km}^{2}$ of fragmented habitat, only partially protected from clearance, mainly in the south-west and west of the island (Rusk 2008a). Within its habitat, legal protection is provided by Mt Hartman National Park (6o ha) and Perseverance Dove Sanctuary ( $32 \mathrm{ha}$ ), thus totalling less than $10 \%$ of the range of the species. Five of the six internationally recognised Important Bird Areas (IBAs) contain Grenada Doves, yet only two of these areas are legally protected (Rusk 2008b). In 1987 and 2007 the global population was estimated roughly to be 50 calling males (100 individuals) and 68 calling males ( 136 individuals), respectively (Blockstein 1988, Rusk 2008a). The upper values reflect the assumption that the sex ratio in the population is equal (Bibby et al. 2000), but in highly threatened populations females are often much less numerous (Donald 2007), so the dove's actual population size may be even lower than the 100 and 136 speculated. More recently, however, a distance sampling survey has produced a population estimate of $160( \pm 30)$ based on 33 doves either heard or observed (Rivera-Milán et al. 2015).

The species faces multiple threats. Dry forest continues to be cleared and fragmented for development, with habitat on private land being particularly vulnerable: in 2007, a hotel development 
was proposed on land adjacent to and within Mt Hartman National Park, threatening habitat availability for approximately $10 \%$ of the global population (Rusk 2008a,b). Elevated predation levels of birds by introduced small Indian mongooses Herpestes auropunctatus, two rat species Rattus rattus and $R$. norvegicus, and feral cats Felis catus are documented throughout the Caribbean (Nellis and Everard 1983, Twyman and Hayslette 2007, Veron et al. 2007, Bennett et al. 2011), and this factor is strongly suspected to impact the Grenada Dove population (Twyman and Hayslette 2007). Hurricanes, such as the category-5 Ivan which struck Grenada in 2004, probably have an effect on dove survivorship (Rusk et al. 2008). Access to fresh water has also been highlighted as a possible limiting factor within the now very restricted range (Rusk et al. 2008, Rusk 2011). Moreover, the continuing low population size is likely to pose a significant long-term risk in terms of genetic loss (i.e. inbreeding depression and reduced adaptive evolutionary potential) and increased vulnerability to stochastic events (e.g. demographic fluctuations and catastrophes) (Frankham et al. 2002).

Clarity over the habitat conditions preferred by the Grenada Dove is needed for immediate management purposes. Mongoose abundance, once measured at 10.4 individuals per hectare at Mt Hartman (Nellis and Everard 1983, Nellis 1989), is one of the highest recorded densities in its introduced range globally, so monitoring of mongoose occupancy is needed to assess the effects of predator control efforts. Evidence of the dove's use of freshwater sources, notably man-made wells, would underscore the value of access to water in the ecology and security of the species. These three aspects were investigated in an eight-week research project from mid-April to midJune 2012.

The study was conducted on the 200 ha Mt Hartman Estate in the south-west of Grenada, of which 60 ha is the Mt Hartman National Park ( $\left.12^{\circ} \mathrm{Oo}{ }^{\prime} \mathrm{N} 61^{\circ} 44^{\prime} \mathrm{W}\right)$, between 11 April and 13 June 2012. The rest of the estate remains unprotected and is destined for development. Approximately half the Grenada Dove population lives within this estate, a former sugarcane plantation that has reverted to dry forest (Rusk 2008a,b). The wider landscape is dominated by residential areas with patches of lowland dry forest; vegetation structure is a complex of thorn woodland and lowland deciduous forest (Rivera Lugo 2005).

Mt Hartman has no permanent watercourses and a rainfall deficit during the dry season, from January to May (Caribbean Environmental Health Institute 2007), but hosts nine man-made wells and watering holes (Rusk 2011). However, the dry season was unusually wet in 2012 (Weather Online 2012), and the birds were territory calling throughout Mt Hartman estate during the study period and one pair was observed starting a nesting attempt.

\section{Methods}

\section{Habitat selection}

Exploratory reconnaissance across the Mt Hartman Estate, 11-18 April 2012, in combination with experience from previous fieldwork, allowed observers to become familiar with discrete areas preferred by Grenada Doves, presumed to be and hereafter referred to as territories, in which calling birds were repeatedly present and breeding behaviour was observed.

During the study, eight exact points at which a Grenada Dove was observed, either perched in the canopy or seen on the ground after calling, were marked with flagging tape for subsequent measurement of habitat variables. At least five individuals were believed to have been involved in the identification of these points, all being located initially by their calling. The points were spread over the Mt Hartman Estate.

For comparison, 12 general habitat points were randomly generated using ArcGIS software from the sample area of dry forest on the peninsula, where no doves had been heard calling according to the last census (Rusk 2008a), stratified to include dove territories up to the boundary dirt road. However, any points $<50 \mathrm{~m}$ from known Grenada Dove territories were rejected as possibly forming part of a territory. The likely presence or absence of Grenada Doves was gauged 
by five-minute point counts after a five-minute settling period (Bibby et al. 2000) on three repeat visits to these 12 points between o6hoo and 11 hoo, with one count completed per point per day. Given that absence of proof is not proof of absence, we also calculated the type II error rate (i.e. the false negative rate). The probability of hearing a call in a potential territory site on a single visit equalled $57 \%$, so the false negative rate (i.e. the probability of erroneously concluding the absence of a dove in our control sites) during three visits was $P=(1-0.57)^{3}=0.080$, and we can therefore be $\sim 92 \%$ confident that a negative control site did not harbour a calling dove.

Habitat variables were recorded at each of the 20 survey points within a standard circular plot of $12 \mathrm{~m}$ radius (0.05 ha) (Bibby et al. 2000, Sutherland 2006). Habitat variables were selected using information about the Grenada Dove's biology (Blockstein 1991, Rusk 2008a). The following data were collected from nine subsampling units within each plot, one at the centre and two on each of the major compass bearings, at $6 \mathrm{~m}$ and $12 \mathrm{~m}$ from the centre (Bibby et al. 2000): mean canopy height of trees $>2 \mathrm{~m}$ tall; canopy depth; canopy density; and estimates of percentage cover for bare ground, fallen dry twigs and each species of plant composing the major vegetation elements.

Canopy height was estimated visually against the value of the tallest tree in the plot, which was measured with a clinometer and trigonometry from highest branch tip to ground directly below, minus any slope. Canopy depth was estimated from maximum canopy height down to $2 \mathrm{~m}$. Canopy density was estimated visually as the number of branches that would intercept a vertical pole from $>2 \mathrm{~m}$ to the maximum canopy height. Two variables used a $0.5 \times 0.5 \mathrm{~m}$ quadrat: (a) bare ground (percentage ground free of living vegetation); and (b) foliage percentage cover of each plant species, from ground to canopy, estimated from above or below (Hawthorne et al. 2004). Mean canopy cover, recorded using a spherical densiometer held $1.5 \mathrm{~m}$ above the ground, was calculated from five points recorded at the centre and $12 \mathrm{~m}$ from the centre in each compass direction. Horizontal foliar density (HFD) was measured using a whiteboard c. $25 \times 45 \mathrm{~cm}$, at heights of $0.5,1$ and $1.5 \mathrm{~m}$ (Hays et al. 1981). For each height, an average HFD was generated from observations $12 \mathrm{~m}$ from the centre point in each main compass direction (Bibby et al. 2000).

\section{Mongoose occupancy and behaviour}

The use of tracking tunnels can help estimate the relative level of mongoose presence in dove habitat by providing a daily presence/absence total that is divided by the total tracking days (number of stations used $\times$ number of days checked). An Occupancy Index, adapted from methodology used by the New Zealand Department of Conservation during control of introduced stoats Mustela erminea (Brown and Miller 1998), is calculated as:

$$
\text { Occupancy Index }=\frac{\sum O}{D . S}
$$

where $O=$ daily occupied stations, $D=$ the number of days, and $S=$ number of stations, e.g. $(10+10+10+10+10) /(5 \times 10)=1$.

Tracking tunnels were constructed from corrugated PVC, $55 \times 11 \times 15 \mathrm{~cm}$. Each aspect of tracking tunnel structure was refined by trial and modified from Black Trakka ${ }^{\mathrm{TM}}$ design with food-dye and sheet paper inserts to record prints. Various non-toxic coloured food-dyes were tested for the maximum number of days they left effective prints. Black glycerine-based food dye lasted 30 days in Grenada dry forest, and left the best prints for up to five days. Each tunnel was placed on areas of level ground (even if the line ran parallel to a slope) and was anchored with wire. Tunnels were baited with $3 \mathrm{~cm}$ pieces of salt fish suspended over the dye pad. Trail cameras (Bushnell) were used to provide additional surveillance information.

An approximately $1-\mathrm{km}$ long monitoring transect line of 10 stations was situated $>0.5 \mathrm{~km}$ from the area where trapping was recently conducted by the Forestry and National Parks 
Department (FNPD). A station was $20 \mathrm{~m}$ wide and consisted of four tunnels laid in a cross each $10 \mathrm{~m}$ from the centre. Each station was placed every $100 \mathrm{~m}$ along the transect line. If at least one of the tunnels contained prints, the station was recorded as occupied (Zielinski and Stauffer 1996). The total number of occupied stations was recorded each day. The line was checked and re-baited daily for five days.

\section{Water source monitoring}

Water was found at four of the nine potential standing water sources. Trail cameras were trialled to optimise camera settings and set to record ten-second videos with a delay of ten seconds between videos. A trail camera was then placed at one of these ('ruin well') from 26 April to 4 May. Cameras were also placed at two wells by stables in the forest adjacent to the visitor centre, $<$ IOO $\mathrm{m}$ from a Grenada Dove breeding pair. The remaining source ('cattle well') was too exposed to the public access track for trail cameras to be used. The footage was classified into observational data. Series of clips were grouped into distinct scenes when the series of events were in sequence, and separated when clips were greater than 10 minutes apart.

\section{Statistical analysis}

An information-theoretic approach was used to assess which logistic regression model best explained habitat selection by Grenada Doves (Burnham and Anderson 2002, Mazerolle 2006). The habitat variables of the two groups, Grenada Dove presence and available habitat, were tested with independent $\mathrm{t}$-tests to determine which variables were significantly different. The assumptions were met (K-S test and Levene's variance), so parametric tests were valid. The variables that were significantly different between the groups $(P \leq 0.05)$ were used in the candidate model selection.

Logistic regression models were used with the binary response variable, dove presence/absence, $I$ or $\mathrm{O}$, as a product of each independent variable. Owing to the small sample size the corrected Akaike information criterion (AICc) was used instead of AIC (Burnham and Anderson 2002, Mazerolle 2006):

$$
A I C c=2 K-2(L)+\frac{2 K(K+1)}{n-K-1}
$$

where $K$ is the number of the parameters in the model including the constant, $n$ the sample size (number of sightings in the breeding territories), and $L$ the maximised value of the likelihood function for the model. These log-likelihood values were obtained from the logistic regression analysis.

Modelling statistical analysis and graphical outputs were completed in SPSS (IBM 2011) and $\mathrm{R}$ software (R Development Core Team 201I). ROC and AUC analysis was conducted using MedCalc for Windows, version 12.3.

\section{Results}

\section{Habitat selection}

Compared to seemingly unoccupied dry forest habitat available for breeding, areas of dry forest at Mt Hartman occupied by calling Grenada Doves (i.e. 'territories') scored significantly higher values in six of the 12 habitat features measured, namely: canopy height, canopy cover, canopy density, fallen dry twigs, bare ground and Haematoxylon campechianum (Table 1).

The best logistic regression model with highest Akaike weight $(\mathrm{AICc}=16.87 ; \mathrm{Wi}=0.79)$ for Grenada Dove habitat selection was the model that only included canopy cover as the predictor 
Table 1 . Plots in Grenada Dove territories $(n=8)$ had significantly higher mean values than the plots in the dry forest without known territories $(n=12)$ for six habitat variables. Means are shown with standard errors, and the significance was calculated with independent t-tests (t) for canopy height, cover and density. Unequal variance $t$-tests $(t)$ calculated the significance of dead fallen twigs, bare ground and Haematoxylon campechianum (Hae. cam.).

\begin{tabular}{lrrrrr}
\hline Variable & GD territory & No territory & $t$ & $P$ & $d . f$. \\
\hline Canopy height $(\mathrm{m})$ & $6.14( \pm 0.51)$ & $4.41( \pm 0.38)$ & 2.71 & $<0.05$ & 18 \\
Canopy cover $(\%)$ & $86.31( \pm 2.12)$ & $74.28( \pm 1.38)$ & 4.76 & $<0.001$ & 18 \\
Canopy density & $3.75( \pm 0.25)$ & $1.75( \pm 0.13)$ & 7.01 & $<0.001$ & 18 \\
Dry fallen twigs (\%) & $78.38( \pm 4.29)$ & $43.58( \pm 7.08)$ & 4.21 & $<0.001$ & 16 \\
Bare ground $(\%)$ & $84.38( \pm 2.90)$ & $58.25( \pm 7.70)$ & 3.17 & 0.01 & 13 \\
Hae. cam. $(\%)$ & $20.38( \pm 4.75)$ & $1.33( \pm 0.74)$ & 3.96 & 0.01 & 7 \\
\hline
\end{tabular}

variable $\left(\chi^{2}=14.71, \mathrm{df}=1, P<0.0001\right.$ ) (see Figure 1 ). Canopy cover had a significant positive relationship with Grenada Dove territory presence (mean $[ \pm \mathrm{SE}]$ coefficient in binary logistic regression: $\beta=0.34[ \pm 0.16])$.

\section{Mongoose occupancy and behaviour}

Mongoose prints were recorded effectively with the tracking tunnel design used, and the presence of mongoose was confirmed by video footage (images of walking through and scent-marking the tracking tunnel are available from NMB). The mongoose occupancy index was 0.98 , which indicates that $\sim 98 \%$ of the mongoose stations were occupied daily in the Grenada Dove territories during the five-day survey period.

\section{Water source monitoring}

The only water source where Grenada Doves were observed was the 'ruin well'. A high proportion of the total observations of drinking columbids involved Grenada Doves (26/73:36\%),

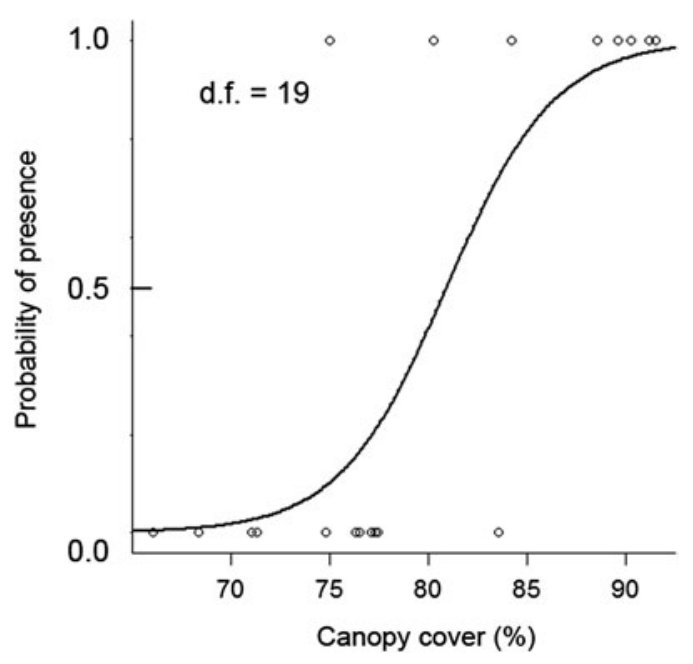

Figure 1. Logistic regression curve for the probability of Grenada Dove habitat selection in dry forest for the best model. Presence of Grenada Dove breeding territory is likely in dry forest with a dense canopy cover. 
second only to the Zenaida Dove Zenaida aurita (30/73:41\%), a widespread species. On three occasions a Grenada Dove was also captured drinking side-by-side with Zenaida Dove and Common Ground-dove Columbina passerina. Introduced predators were also filmed using the same well.

\section{Discussion}

\section{Habitat selection}

Canopy cover appears to be the most significant environmental variable characterising Grenada Dove territories, and this supports the findings of previous work (Blockstein 1988, Rivera Lugo 2005). Canopy cover was also identified as the most significant habitat determinant in the congeneric White-tipped Dove Leptotila verreauxi in Texas (Hayslette et al. 200o). Grenada Doves are rarely seen crossing gaps in the canopy in flight, preferring to walk (Rusk 2008a), and when alarmed they will fly to the ground and flee on foot (B. L. Rusk pers. comm.). Other features of the habitat are undoubtedly important as well, but owing to the nature of the test needed for the relatively small sample sizes (the corrected Akaike information criterion, AICc), only one environmental variable was identified in this study. Furthermore, other wooded habitats will be important to the species for non-breeding purposes as well: a trail-camera set for mongooses recorded a Grenada Dove walking through dry forest in an area where no calling males had been heard or seen.

The proxy of recording doves on the ground in their territories may be a source of noise or uncertainty in the data. Some territories could have been missed in this short study because the likely presence/absence of doves was determined based on five-minute point counts. Hence, we could have mislabelled habitat as being unsuitable for territories. Given this uncertainty, and despite the small sample size, there were still significant differences detected, which suggest that canopy cover must be a strong environmental determinant for dove territory presence at $\mathrm{Mt}$ Hartman. Further study, extended to the other subpopulations, is needed to establish the full habitat requirements of the Grenada Dove.

\section{Mongoose occupancy and behaviour}

In the 1970s-1980s an extensive island-wide control programme on mongooses was carried out to alleviate the incidence of rabies and remove the mongoose disease reservoir. However, these 2012 results indicate that mongoose levels have now recovered to the point of near-complete daily penetration of the dove's habitat. Monitoring the occupancy index before, during and after mongoose control programmes will yield valuable data to assess the efficacy of these measures and establish their likely impact on dove predation risk.

A trail-camera also captured evidence of a mongoose leaping into a young tree, indicating that these animals can jump vertically as well as run up fallen trees (Cosgrove 2008) and thus may be able to access Grenada Doves' eggs and young, although rats and feral cats detected by the trailcameras pose a threat to nesting success and dove survival.

\section{Monitoring water sources}

One of the standing water sources, the 'ruin well', was found to be frequently used by Grenada Doves, building on the results of the previous study (Rusk 2011). This well was due to be removed to make way for a hotel development. The two 'stable wells' recorded no Grenada Dove use in this short study; they are close to areas with relatively high levels of human activity, which may explain the apparent absence. Similarly, no Grenada Doves were observed using the 'cattle well', again perhaps owing to regular disturbance by human activity, tethered livestock or a lack of cover. The 'ruin well' had good canopy cover $(85 \%)$ and its recorded use with 
camera traps indicates that well removal might have serious negative impacts on the Grenada Dove population at Mt Hartman.

All the potential introduced predators of Grenada Doves were observed using the threatened 'ruin well'. Moreover, Grenada Doves were witnessed drinking alongside several columbid and other bird species. This has health implications relating particularly to trichomonosis, a water-borne disease spread via Trichomonas gallinae, and mosquito-carried avian malaria (Fallon et al. 2005). Drip-fed or 'leaky' hose water stations have been introduced in Mauritius to reduce disease spread and dependence on standing water (NMB/DJB pers. obs.).

\section{Conservation and further research recommendations}

Populations of extremely rare species with multiple synergistic extinction drivers can suddenly and rapidly decline after years of lag-time (VanderWerf et al. 2006). For at least 20 years the population of the Grenada Dove has remained stable but very low, although conservation management proposals (Rusk et al. 2008) have established demanding but realistic targets for a steady population recovery. Here we supplement the detailed plans set out in Rusk et al. (2008), and reinforce the general call for predator control and habitat restoration in Rivera-Milán et al. (2015), with certain management and research activities which experience in 2012 suggests are most urgently needed, in approximate order of perceived priority.

(I) Undertake an intensive, scientifically planned control programme to minimise mongoose presence at all sites where doves survive (Rusk 2008b) involving the community and stakeholders, within the framework of a programme to monitor dove population response. (2) Monitor and control (or rehome) other introduced predators such as rats, opossums, dogs and cats, especially at dove nests, avoiding unintentional mesopredator release. (3) Census the entire population of doves robustly to establish a firm baseline, monitor nesting success rates and identify causes of nest failure by remote camera surveillance, and establish a simple but rigorous long-term monitoring programme for the numbers of doves and exotic predators. (4) Band and sample as many doves as possible to determine home range sizes, sex ratio, genetic diversity and various life-history parameters, as well as to aid population monitoring. (5) Continue habitat use data collection to confirm the dove's preferences, across all sites for the species (Rusk 2008b, Rivera-Milán et al. 2015), spot-mapping all territories, assessing the total area of suitable habitat, investigating the influence of hurricanes on canopy cover and implementing measures to promote improvements in canopy cover as soon as the value of this feature is confirmed. (6) Conduct trials to determine if Haematoxylon campechianum is important to the dove, and implement appropriate planting programmes if the result is positive. (7) Experiment with drip-fed water stations from collected rainwater to determine their utility in increasing dove occupancy of habitat and to reduce risk from potential pathogens such as Trichomonas gallinae (if present in Grenada: easy to screen in birds shot as pests), imported by exotic columbids.

\section{Acknowledgements}

We warmly thank the Rufford Small Grants Foundation (RSG), Chester Zoo, Zoological Society for the Conservation of Species and Populations (ZGAP), Thrigby Hall Wildlife Gardens and The Sir Phillip Reckitt Educational Trust for their financial support of the fieldwork; Bonnie L. Rusk, Director, Grenada Dove Conservation Programme, Aden Forteau, Chief Forestry Officer, Forestry and National Parks Department, Anthony Jeremiah, Conservation Officer, Forestry and National Parks Department, Peter Plenty, Antonette Dragon, Ketichia Calliste and Alicia Horseford at Mt Hartman National Park, and Doland Francis at Perseverance Dove Sanctuary for their generous cooperation; David C. Wege at BirdLife International for general support; and Lucy Garrett for assistance in the field. We particularly thank Bonnie Rusk for suggestions which greatly improved the manuscript. 


\section{References}

Bennett, C. E., Wilson, B. S. and Desalle, R. (2011) DNA barcoding of an invasive mammal species, the small Indian mongoose (Herpestes javanicus; E. Geoffroy SaintHillaire [sic] 1818) in the Caribbean and Hawaiian Islands. Mitochondrial DNA 22: $12-18$.

Bibby, C. J., Burgess, N. D., Hill, D. A. and Mustoe, S. (2000) Bird census techniques. Second edition. London, UK: Academic Press.

BirdLife International (2014) Species factsheet: Leptotila wellsi. Downloaded from http:// www.birdlife.org on O1/04/2014.

Blockstein, D. E. (1988) Two endangered birds of Grenada, West Indies: Grenada Dove and Grenada Hook-billed Kite. Caribbean J. Sci. 24: 127-136.

Blockstein, D. E. (1991) Population declines of the endangered endemic birds on Grenada, West Indies. Bird Conserv. Internatn. 1: 83-91.

Brown, J.A. and Miller, C. J. (1998) Monitoring stoat (Mustela erminea) control operations: power analysis and design. Science for Conservation 96 (Department of Conservation, New Zealand).

Burnham, K. P. and Anderson, D. R. (2002) Model selection and multimodel inference: a practical information-theoretic approach. Second edition. New York: Springer.

Caribbean Environmental Health Institute (2007) Geographical Information Systemassisted water availability analysis for Grenada. Castries, St. Lucia.

Cosgrove, P. (2008) Grenada Dove Leptotila wellsi response to non-native ground predators. Cotinga 30: 72-73.

Devas, R. P. (1943) Birds of Grenada, St. Vincent and the Grenadines. First Edition. St Georges, Grenada: Carenage Press.

Donald, P. F. (2007) Adult sex ratios in wild bird populations. Ibis 149: 671-692.

Fallon, S. M., Bermingham, E. and Ricklefs, R. E. (2005) Host specialization and geographic localization of avian malaria parasites: a regional analysis in the Lesser Antilles. Amer. Nat. 165: 466-480.

Frankham, R., Ballou, J. D. and Briscoe, D. A. (2002) Introduction to conservation genetics. Cambridge, UK: Cambridge University Press.
Hawthorne, W., Jules, D. and Marcelle, G. (2004) Caribbean spice island plants. Oxford: University of Oxford Forestry Institute, Plant Sciences.

Hays, C. R. L., Summers, C. and Seitz, W. (1981) Estimating wildlife habitat variables. Washington, DC: US Fish and Wildlife Service (Western Energy and Land Use Team).

Hayslette, S. E., Tacha, T. C. and Waggerman, G. L. (2000) Factors affecting white-winged, white-tipped, and mourning dove reproduction in Lower Rio Grande Valley. J. Wildl. Mgmt. 64: 286-295.

IBM (2011) IBM SPSS Statistics for Windows, Version 20.0. Armonk, NY: IBM Corporation.

Mazerolle, M. J. (2006) Improving data analysis in herpetology: using Akaike's Information Criterion (AIC) to assess the strength of biological hypotheses. Amphibia-Reptilia 27: 169-180.

Nellis, D. W. (1989) Herpestes auropunctatus. Mammalian Species 342: 1-6.

Nellis, D. W. and Everard, C. O. R. (1983) The biology of the mongoose in the Caribbean. Stud. Fauna Curacao Caribbean 64: 1-162.

R Development Core Team (2011) R: A language and environment for statistical computing. Vienna, Austria: R Foundation for Statistical Computing.

Rivera Lugo, P. J. (2005) Composition and structure of Grenada Dove (Leptotila wellsi) habitat. Grenada Dry Forest Biodiversity Conservation Project, unpublished report.

Rivera-Milán, F. F., Bertuol, P., Simal, F. and Rusk, B. L. (2015) Distance sampling survey and abundance estimation of the critically endangered Grenada Dove (Leptotila wellsi). Condor 117: 87-93.

Rusk, B. L. (2008a) Grenada Dove (Leptotila wellsi) census 2007. St. Georges, Grenada, unpublished.

Rusk, B. L. (2008b) Grenada. Pp.175-182 in D. C. Wege and V. Anadón-Irizarry, eds. Important Bird Areas in the Caribbean. Cambridge, UK: BirdLife International.

Rusk, B. L. (2011) Water sources on the Mt Hartman Estate: management recommendations for the Grenada Dove. St. Georges, Grenada, unpublished. 
Rusk, B. L., Forteau, A., Wege, D., Blockstein, D., Temple, S., Wallace, G. and Sorenson, L. (2008) Recovery and action plan for the Grenada Dove Leptotila wellsi. Unpublished draft.

Sutherland, W. J. (2006) Ecological census techniques: a handbook. Second edition. Oxford, UK: Oxford University Press.

Twyman, W. D. and Hayslette, S. E. (2007) The Grenada Dove: habitat descriptions, foraging behavior, potential predators, and human influences. Presented at the 30 th Annual Meeting of the Tennessee Chapter of The Wildlife Society, Townsend, Tennessee, USA.

VanderWerf, E. A., Groombridge, J. J., Fretz, J. S. and Swinnerton, K. J. (2006) Decision analysis to guide recovery of the po'ouli, a critically endangered Hawaiian honeycreeper. Biol. Conserv. 129: 383-392.

Veron, G., Patou, M.-L., Pothet, G., Simberloff, D. and Jennings, A. P. (2007) Systematic status and biogeography of the Javan and small Indian mongooses (Herpestidae, Carnivora). Zoologica Scripta 36: 1-10.

Weather Online (2012) Point Salines Airport precipitation $(\mathrm{mm})$. Weather Online. co.nz. URL http://www.weatheronline.co.nz/ weather/maps/city.

Zielinski, W. J. and Stauffer, H. B. (1996) Monitoring Martes populations in California: survey design and power analysis. Ecol. Appl. 6: $1254-1267$.

N. M. BOLTON*, D. J. BELL

School of Biological Sciences, University of East Anglia, Norwich Research Park, Norwich, $N_{4} 7$ TJ, UK.

C. van OOSTERHOUT

School of Environmental Sciences, University of East Anglia, Norwich Research Park, Norwich $\mathrm{NR}_{4}{ }_{7} \mathrm{TJ}, \mathrm{UK}$.

N. J. COLLAR

BirdLife International, Girton Road, Cambridge $\mathrm{CB}_{3}$ oNA, UK and School of Biological Sciences, Norwich Research Park, University of East Anglia, Norwich NR4 7TJ, UK.

*Author for correspondence; email: nicholas.bolton84@gmail.com

Received 8 September 2014; revision accepted 21 March 2015; Published online 30 April 2015 